\title{
TRADITIONAL GOVERNANCE STRUCTURES - CURRENT POLICY PRESSURES: THE ACADEMIC SENATE AND CANADIAN UNIVERSITIES
}

\begin{abstract}
The objective of this paper is to identify current policy pressures in Canadian higher education and explore their implications for academic decision-making bodies based on data we obtained in our national study on university senates. We describe two inter-related sets of public policy pressures that have emerged in recent years in Canada including on-going financial restraint and a renewed interest in university research. We conclude by reviewing a number of important implications for Canadian university governance in the context of contemporary policy pressures.
\end{abstract}

\section{INTRODUCTION}

This paper examines the academic senate within the context of university governance in Canada in conjunction with two inter-related policy pressures that have emerged over the past 25 years. The first pressure is fiscal restraint in government operating grants starting in the 70s. The second is the changing priorities in government research funding for universities, beginning in the $80 \mathrm{~s}$, toward applied and market-oriented efforts that can be said to foster Canadian private sector competitiveness related to globalisation. Our objective in this paper is to analyse these two current policy pressures in Canadian higher education and explore their implications for academic decision-making bodies drawing upon data from a national study on university senates. ${ }^{1}$ We begin by discussing university governance in Canada and provide a brief historical context for our analysis, followed by a description of the research design of this study and the presentation of the general findings. Then we consider each set of policy pressures in relationship to specific data from the study that pertains to each issue. Finally, we discuss possible implications of our findings and offer conclusions.

\section{UNIVERSITY GOVERNANCE IN CANADA}

There is an emerging body of higher education literature that provides a historical overview of university governance in Canada. This liter- 
ature suggests that as a result of the 1906 Royal Commission on the University of Toronto, Canadian universities gradually adopted bicameral governance structures (Cameron 1991; Jones 1996; Jones, Shanahan \& Goyan 2001; Jones \& Skolnik 1997). In reviewing the relationship between the University of Toronto and the Government of Ontario, the Commission argued that the University should be 'divorced' from 'the direct superintendence of political powers' and that Government authority over the institution should be delegated to a corporate board, largely composed of respected citizens appointed by government (Alexander 1906, p. 276). At the same time, the Commission argued that the academic senate, composed primarily of senior scholars and academic administrators, should be retained, and that there should be a division of responsibility between the corporate board, assigned authority for the 'administrative affairs' of the institution, and the senate, assigned responsibility for 'academic affairs'. While several other institutions had already experimented with bicameral structures, the report of the Royal Commission provided a clear framework for bicameral governance and the Act drafted by the Commission was quickly approved by the Government of Ontario. This Act, in turn, was used as a model by the emerging institutions in Western Canada. By the 50 s, almost all Canadian universities had adopted some form of bicameral governance structure.

Almost every Canadian university reviewed its governance arrangement during the period from 1964-1972. The governance reform process was influenced, at least in part, by a national study conducted by Sir James Duff and Robert Berdahl (1966). Duff and Berdahl argued that the reform of university governance could be accomplished within the framework of bicameralism: faculty should have a voice on university governing boards, students should have a voice on university senates, there should be more interaction between senates and boards, and the entire governance process should become more open and transparent.

The commissioners reported that 'we have formed the firm opinion that the ineffectiveness of senates is the major cause of the tension and disharmony that exist today, not in all, but in far too many Canadian universities' (Duff \& Berdahl 1966, p. 9). However, they rejected the Oxford and Cambridge model where faculty had absolute powers of selfgovernment because of 'its incapacity for self-reform' (p. 13). Even so, Duff and Berdahl noted that Canadian senates differed from their counterparts in the United Kingdom and the United States in that historically they had included substantial participation by non-faculty. The commissioners recommended that long-term academic planning should be a cooperative effort between the board, senate and administration. Similarly, they recom- 
mended that the senate should participate in the university-wide budget process and undertake periodic reviews of departmental and faculty affairs. Duff and Berdahl also recommended that the size of the senates should be reduced with a maximum size of approximately 50 members in order to improve effectiveness and efficiency

The actual changes that took place varied by institution, but almost all universities revised their governance structures to allow for faculty and student representation on the governing board and increased student representation on the university senate without reducing the overall size of the senate. By the early $70 \mathrm{~s}$, most university senate meetings were open to the general public and university boards began to adopt similar (though more limited) procedures in order to increase the transparency of the decision-making process.

Interest in governance arrangements was reawakened in the mid-70s by the movement towards faculty unionisation on many university campuses and, more recently, by concerns regarding the capacity of institutional decision-making structures to respond to emerging policy pressures. If the governance reform process represented an attempt to create a balanced form of participatory decision making, then faculty unionisation, it has been argued, shifted that balance in favour of the professoriate (Cameron 1992). However, the development of faculty unions may have reduced the power of the university senate. Following the rise of unionisation, interest in university governance began to wane. There has been relatively little empirical research on university governance since the $70 \mathrm{~s}$.

\section{RESEARCH DESIGN}

The study included collection of data on the basic structure, composition and role of Canadian university senates obtained from senate secretaries. We also asked senate secretaries for their personal opinions on the most important issues or problems associated with these governing bodies. This was followed by a survey of senate members to determine their perceptions of the senate's role and effectiveness, the role of senate members, and the nature of their work.

The sample population included all independent degree-granting institutions in Canada (including university colleges) listed by the Association of Universities and Colleges of Canada (AUCC) but excluded affiliated institutions, institutions that do not award secular degrees, and the (federal government-supported) Royal Military College. A total of 67 institutions were identified and questionnaire packages were mailed to senate secretaries in November of 1998 . Responses were received from $42^{2}$ institutions 
for a response rate of $63 \%$. Responses were received from institutions in all Canadian provinces except Saskatchewan. The following phase of the study involved a survey of all senate members at institutions participating in the first component of the study. Thirty-eight institutions agreed to participate and bilingual questionnaires were distributed to 2,250 senate members. A total of 869 responses were received from senate members for a response rate of $40 \%$ (after adjusting for questionnaires that were undeliverable).

\section{SENATE Composition AND ROLE}

Our findings on senate composition and role are taken up in detail in earlier papers (Jones, Shanahan \& Goyan 1999, 2000, 2001), but a review of some of these findings will assist the reader in understanding some features of Canadian university senates. Faculty form the largest category of members of university senates, comprising approximately $44 \%$ of the total membership, and students are the second largest membership category (18\%). Approximately three-quarters (30 of 38) of university senates are chaired by the president. The vast majority of university senates include ex officio positions for senior university administrators, including the university president ( $90 \%$ of senates), vice presidents and deans (76\% of senates), and other senior administrators ( $83 \%$ of senates). In aggregate terms, these administrative positions represent approximately one-quarter of total senate membership. Other categories of membership included non-academic staff $(6 \%)$, representatives of the university board $(3 \%)$, representatives of affiliated colleges $(2 \%)$, alumni $(2 \%)$, and government appointees $(0.5 \%)$. The average number of voting members per senate was 61.

There is considerable variation in the role and responsibilities assigned to the senate at Canadian universities. While at most institutions the senate has authority over major academic decisions, such as the approval of new courses and establishing admissions standards (89\%) and establishing educational policy (87\%), there are significant differences in the range of responsibilities and the level of authority. At some institutions the senate has been assigned a broad role of advising the governing board on academic matters, while at others the senate has a more narrowly defined mandate and executive responsibility over specific areas of decision making. A slight majority of respondents (20 out of 39 completed responses, or $51 \%$ ) indicated on the survey that the senate plays some form of formal role in the university's annual budget or financial

allocation process. It should be noted, however, that when the legislative 
documents were examined an explicit senate role with respect to the institutional budgetary process could be found in only seven of the institutions surveyed $(18 \%)$.

\section{FACING FINANCIAL RESTRAINTS}

Following World War II there was tremendous growth in enrolments and funding as post-secondary education came to be viewed as an important tool for post-war industrialization and economic expansion. During this time, universities in Canada made the transition 'from private domain to public utility,' or from 'nobody's business' to 'everybody's business' (Corry 1970). In large part, this growth and expansion of the university sector was made possible through the financial assistance of the federal government, even though education is a provincial responsibility under the Canadian constitution. In addition to its primary role as funder of university research, the federal government began providing per capita grants directly to the universities in 1951. As a result of Quebec's objection that direct grants to universities intruded upon provincial jurisdiction, in 1967 the federal government introduced a system of cash transfers and tax points to the provinces designed to cover $50 \%$ of the direct operating costs of post-secondary education. In addition, the federal government provided funding for capital infrastructure.

The growing dependence on government grants in the $60 \mathrm{~s}$ and the arrival of an extended period of funding restraint beginning in the early $70 \mathrm{~s}$ resulted in tension between traditional notions of institutional autonomy and that of the university as a tool of public policy. When the economy entered into recession in the early 70 s, restraint became a key policy term and high education went from being viewed as a top priority to an area for funding reductions or restraint. Although enrolments generally continued to increase, funding did not keep pace and the universities began arguing that there was a 'crisis of under-funding'. Facing a period of funding uncertainty and job insecurity, faculty in many institutions unionised. Although reforms to internal governance had just taken place, Crispo wrote that there was a 'shift from what has been believed to have been collegial, deliberative and participatory relations to what is perceived as being adversary, bargaining and contractual relations ... from a community of scholars to a community of protagonists' (Axelrod 1982, p. 212).

Since the 60s, however, there had also been substantial growth in university administration as presidents hired planning specialists, budget directors, and vice-presidents as a new managerialism took hold in the academy. Axelrod characterises the period saying: 'Poor communications 
among presidents, boards, university senates, and faculty associations had frequently produced tension and mistrust in the planning and decisionmaking processes' (Axelrod 1982, p. 212). Whereas Duff and Berdahl had argued that senates must be involved in institutional planning and the budgetary process, in most instances this did not take place as presidents, weakened by the earlier reforms, consolidated these new areas under their direct control or generally worked with the governing boards on budgetary and planning matters.

Changes in higher education funding levels in the 70 s led to a deterioration of relations between universities and government so that 'a situation of two solitudes has emerged and created an unhealthy state of affairs' (MacDonald 1976, p. 51). Although funding cuts were temporary in the 80 s continuing increases in enrolments and long-term funding restraint led to a situation where the operating grant per student declined steadily. Buchbinder and Rajagopal report that: 'From 1980 to 1990, there was an enrolment increase of more than $30 \%$ across Canada while operating grants during the same period rose only 3\% in real dollars' (1993, p. 271).

Hardy (1996) studied the approaches taken to retrenchment at six Canadian universities in the late $70 \mathrm{~s}$ and early $80 \mathrm{~s}$ in response to cutbacks or restraint in provincial operating grants. It is interesting to note the variety of approaches taken by the institutions and the extent of involvement in decision-making by the senates. Based on Hardy's analysis it appears that the senate often did not play a role in retrenchment decisions even when programme closures were involved or the senate was co-opted to provide the appearance of collegiality and consultation. In several cases, presidents chose to appoint their own committees made up wholly of senior administrators or a combination of faculty and administrators.

Government debt continued to grow throughout the 80s. As a percentage of Gross Domestic Product, government debt rose from 12.0\% in 1979 to $26.1 \%$ in 1984 and $40.3 \%$ in 1990 (Slaughter \& Leslie 1997, p. 33). Beginning with the election of the Conservative (neo-liberal) government under Brian Mulroney in 1984, there began a new public discussion on the need to control public spending and to increase industrial competitiveness in the new global economy. The universities were to play a critical role in helping Canada succeed globally, yet were criticised for their inefficiency and lack of market relevance. Despite their ability to educate ever-increasing numbers of students at lower unit costs, universities were perceived as inefficient and out of touch (Cutt 1990; Paquet 1988). With the signing of the Canada-US Free Trade Agreement, followed by the North America Free Trade Agreement, there was 
increasing attention on the role of post-secondary education in training workers to meet the competitive needs of business as well as demands for greater utility and relevance of university research.

The greatest impact in terms of funding restraint would not occur, however, until the mid- and late-90s. Beginning in the late $80 \mathrm{~s}$, the federal government first reduced, then eliminated, the growth escalator for cash transfers to the provinces for post-secondary education. In late 1994, the federal government announced that it was eliminating the Established Programs Financing mechanism and replacing it with the Canada Health and Social Transfer for health and post-secondary education. This resulted in a loss to the provinces of $\$ 2$ billion in cash transfers for post-secondary education.

With the exception of British Columbia, provinces have reduced operating grants to universities in real dollar terms during the 90s. The most significant reductions occurred in Alberta $(-21 \%$ over 3 years) and Ontario ( $-15 \%$ in 1996/97). On average, unconditional provincial operating grants to universities declined from $81.1 \%$ of operating income in $1987 / 88$ to $64.5 \%$ in $1997 / 98$. During the same time, most provinces allowed universities to raise student tuition which increased from $16.3 \%$ of operating income in 1987/88 to $30.6 \%$ in $1997 / 98$ (Council of Ontario Universities 2000 , p. 18). In many jurisdictions, provinces have begun to reinvest in post-secondary education through the use of targeted funding mechanisms rather than through unconditional operating grants.

Our survey of senate members' views on their role and the work of the senate provides an interesting perspective on how the senate has - or has not - contributed to positive adjustment to long-term funding restraint. Some results from the survey pertaining to fiscal restraint are summarised below. Concerning the role of the senate, $68.5 \%$ of respondents agreed that it should confine itself mainly to academic matters, although agreement was highest among administrators (82.6\%) and lowest among students (48.5\%). Almost the exact same percentage of respondents $(68.3 \%)$ agreed that the senate does confine itself mainly to academic matters. There was very strong agreement $(90.1 \%)$ that the senate should be the final authority for approving academic policies, whereas in practice only $74.3 \%$ agreed that this was the case. Although $59.0 \%$ of respondents agreed that the senate should play a major role in the university's budget process, $57.4 \%$ disagreed that the senate actually does play such a role. A majority of faculty $(67.3 \%)$ supported a budget role for the senate, whereas only $37.1 \%$ of administration supported such a role. These findings are notable given that the Duff-Berdahl governance reforms of the 60 s specifically recognised the importance of the senate's involvement in financial decisions. 
Arguably recommendations for the bicameral reforms sought to link the financial and academic planning functions of the institutional.

There is evidence that the administration is gaining in power with its heavy representation on the senate and its ability to influence the governing board. Following the governance reforms of the late 60 s and early $70 \mathrm{~s}$, critics argued that while the new arrangements dramatically strengthened academic self-government, they also weakened what Cameron refers to as 'corporate autonomy' and in doing so decreased the powers and autonomy of the university president (Cameron 1992). The survey results may suggest that the pendulum is once again shifting power in favour of the governing board and senior administration.

Universities are often accused of failing to make tough decisions, instead choosing to apply funding cuts across-the-board. Governments call for programme rationalisation based upon relevance and for greater efficiency. Cameron (1992) has pointed to the need for greater corporate autonomy on the part of governing boards as a possible solution. Even so, the senate is generally - perhaps unfairly - viewed as being the weakest component of university governance. As pointed out by Duff and Berdahl 25 years ago, senates could not be effective unless their size is reasonable and unless their activities are linked into institutional planning and budgetary processes. Findings from our study indicate this is not the case for the majority of senates in Canada. Perhaps this explains why senate secretaries noted that academic decision-making in the context of fiscal restraint is one of the greatest challenges facing senates today.

Funding restraint has had a major impact on universities in Canada over the past 30 years. It has contributed to creating a situation of resource dependence resulting in universities seeking out alternative sources of funding for research and other activities. This trend is best demonstrated by looking at developments in university research as institutions face everincreasing demands that they be relevant to market needs and foster private sector competitiveness.

\section{RENEWED INTEREST IN UNIVERSITY RESEARCH}

Many of the trends in Canadian higher education are reflective of broader international trends and have been attributed by some scholars to the influence of globalisation. A fundamental feature of globalisation is the organisation and integration of economic activity at the transnational level. It is evidenced in national higher education policy in the emphasis on international economic competitiveness. In a globalising environment education becomes increasingly vocationalised as higher education policy 
shifts, emphasising relevance and response to the labour market's needs and training for employment to meet the demands of business and industry in the name of competitiveness (Currie \& Newson 1998; Slaughter \& Leslie 1997; Rhoades 1998; Newson \& Buchbinder 1990).

As a result of the globalisation of national economies, it is argued in the literature that significantly smaller amounts of public money are available for public sector activities such as higher education as governments target debt and deficit reduction in order to enhance their competitiveness in the global marketplace (Slaughter \& Leslie 1997; Currie \& Newson 1998). Universities faced with these cutbacks begin to seek out alternative, innovative revenue sources. At the same time, scarce resources make potential revenue generating activities such as research, and in particular applied research, more valued in the university because they are often critical to an institution's survival.

Discussions of globalization within Canada have come to be associated with 'academic capitalism' where the market plays a stronger role in universities than before and university activities are steered in the direction of market needs and priorities (Currie \& Newson 1998; Newson 1992; Slaughter \& Leslie 1997). While Slaughter and Leslie (1997) found Canada trailed other jurisdictions in the manifestations of globalisation in its higher education landscape based on their review of the $80 \mathrm{~s}$, there is now strong evidence of changes in Canadian higher education particularly research policy.

The specific challenge for Canada's federal government in responding to this change lies in developing a national research infrastructure in a context where higher education policy has been decentralised and jurisdiction over education has been constitutionally relegated to the provinces. The role of the federal government in terms of direct co-ordination of post-secondary education in Canada is minor, but it is important to note that the federal government has a major role as a funder of university-based research in Canada. It is the largest source of support for academic research at universities, giving it considerable influence over an important aspect of university activities. In the past the federal government's support of university research was confined to three main granting councils: the Medical Research Council, the Natural Sciences and Engineering Research Council and the Social Sciences and Humanities Research Council. The councils provided support for the direct cost of investigator-initiated research activity through a peer-reviewed selection process. However, the councils did not support the indirect costs of research (overhead, administrative costs and faculty time) that were inevitably absorbed by the universities. 
Although the 80 s saw an overall increase in the federal government's support of university research in the 90 s overall funding support declined in real terms with the federal government gradually reducing its role as a funder and performer of research in order to address budget deficits. A key policy objective of the federal government was to adopt a new role as a catalyst and initiator of research, rather than funder and provider of research, by increasingly using leveraging mechanisms to support research efforts (AUCC 1999a). ${ }^{3}$ In response, universities have become innovative in their search for alternative sources of research funding. This has led to an overall increase in university interaction with industry in Canada encouraged by government funding policies and with the support of the three main granting councils. The role of the private sector as both a funder and a consumer of university research has increased in Canada. ${ }^{4}$ University research has become more applied and there has been an increase in university involvement in the commercialisation of research. There has been a shift in the balance of government funding of research away from discipline-based, curiosity-driven, basic research towards research projects that are issue-based and conducted by collaborative, multi-institution centres or networks that target areas and sectors deemed to be strategic for economic growth.

At the end of the decade, changes signifying a strengthening of the federal government's role in Canadian higher education and suggesting a renewed commitment to university research became apparent. The federal government announced in the 1998 federal budget that it would restore funding to the granting councils to the 1994/95 levels and increase the total amount spent by $\$ 400$ million by 2001 . It has also introduced major new initiatives that have reorganised some areas of research, improved research infrastructure and enhanced research funding at Canadian universities. For example in 1997 the Canadian Foundation for Innovation (CFI) was established which provides funds for universities, hospitals, and other not-for-profit institutions by investing in the development of research infrastructure (Canada Foundation for Innovation 2000). In addition, the federal government established the Canada Research Chairs Program (CRC) that will enable universities and affiliated research centres and hospitals to create 2000 new research chairs by the year 2005 to attract outstanding researchers (Jones 2000). Research in health has also been reorganised at the federal level with the creation of the Canadian Institute of Health Research (CIHR) which replaces the Medical Research Council, one of the major granting councils, and becomes the major federal agency responsible for organising and funding research in health (CIHR 2000). The magnitude of the funding for the federal initiatives is enormous and the 
commitment of federal funds is guaranteed for three years signifying an ongoing increase in the federal government's involvement and influence in the broader Canadian higher education policy.

Government investment in higher education research in Canada is not exclusively at the federal level. Increasingly provinces are playing a significant role. Some Canadian provinces have made a similar commitment to university research by developing comparable provincial versions of the above programmes to financially support and encourage innovation in research (e.g. the provinces of Ontario, Alberta, and Quebec all have provincial versions of the CFI or similar strategic research initiatives) although there are variations by province with regard to the extent and form of government research funding and the growth of research activities. Notwithstanding these current developments, universities are still suffering from the cumulative effects of declining core funding over the past decade (AUCC 1999b). Cuts to their core operations have made it difficult to take full and immediate advantage of these new research investments.

Moreover, while the infusion of funds into Canadian university research is welcomed, it comes with strong external pressure for institutions to move in certain directions within a fairly short period of time and without much debate from university constituencies.

The implications for the senate in Canadian universities are two fold: diminished control over the future direction of internal research activities (and by extension other related academic policies such as extent of programme diversity), and diminished control over institution's ability to define its academic direction and research character within the system if it is not favoured in the funding awards. The dramatic steering effect of research and by extension academic policy of these initiatives coupled with the fact that the senate does not appear to have a strong role in coordinating the initiatives could signal the senate's exclusion from strategic decision-making associated with important research developments at universities.

These issues raised questions for us in our study about the senate's ability to determine the strategic direction of the institution. One aspect of this theme was the apparent reluctance of the senate to deal with change: reluctance that at least some senate secretaries believed was inappropriate in a rapidly changing environment. One respondent concluded, rather ominously that 'their inability to change may make them obsolete'. A second aspect of this theme involved the challenge of establishing new types of policy as required in a rapidly changing environment. Several senate secretaries noted that the senate was now involved in new policy areas involving complex issues. They expressed concern that the senate 
was finding it difficult to reform to be representative and responsive to the broader community.

Our findings also suggest that senate members are struggling to resolve the disparity between the role they believe the senate should play and the role it actually does play. There was also the sense from our findings that the senate's power was declining in comparison to the university administration and governing board. $63 \%$ of respondents disagreed that the authority of the senate is increasing in comparison to the university administration and governing board. Respondents were also asked about the senate's role in four key areas as follows: establishing research policies; determining strategic directions; determining priorities for fundraising and development; and, determining the future direction of the university. Respondents indicated that the senate should play a role within the university in establishing research policies $(77.9 \%)$, whereas only $43.9 \%$ indicated that the senate actually does establish research policies at their university. Similarly, when asked about the senate's role in determining strategic directions of the university most $(55.5 \%)$ agreed the senate should play such a role, at the same time most $(53.7 \%)$ indicated that the senate did not actually determine strategic directions. When asked about the senate's role in determining priorities for fundraising and development most members agreed (50.5.2\%) that the senate should play a role, but strongly indicated $(65.1 \%)$ that the senate did not play such a role. Finally, members agreed the senate should play a role in determining the future direction of the institution (89.2\%). While many respondents (43.2\%) agreed that the senate did play such a role, a large number disagreed $(33.2 \%)$ responding that the senate did not actually play a role in determining the future direction of the institution.

\section{Conclusion: Policy PRessures and the University Senate}

It is clear from the current policy trends in Canadian higher education that university research has been prioritised as an important component of the country's economic development. Given the magnitude of the recent funding initiatives, and the fact that they come after decades of fiscal restraint, one might expect the university senate to be more involved in related academic decision-making associated with planning and setting institutional directions. The findings from our study suggest that most senates play a limited role in this important area of academic decision-making. 
Fashioning the institution's academic response to these complex policy issues is the responsibility of the university senate as the internal academic decision-making body. However, data from our study suggests that role ambiguity and effectiveness are issues for contemporary senates at Canadian universities. Our data suggests there is a disparity between the role senate member's feel the senate should play and the role the senate actually does play which we would argue diminishes its ability to respond effectively to contemporary challenges. Complex issues surrounding research and development, globalisation and funding constraints, are coalescing in a policy environment that is both promising and demanding for higher education institutions. Decision-making bodies are expected to respond swiftly and decisively. It is unclear whether the senate has the capacity for this type of response

Particularly relevant are our findings that senate members do not feel the senate is playing the role it should in areas such as: establishing research policies; determining strategic research directions; determining priorities for fund raising and development; and determining the future direction of the institution. To compound matters senate members feel they should have a stronger budget role that one might argue is critical to fashion an appropriate institutional response in times of cuts and fiscal restraint. However, it is difficult to understand how this role might best be realised if in most instances the senate is not involved in determining priorities for fundraising and development or in the budget process. Given these findings, our study raises questions about the effectiveness of the senate as a decision-making body.

\section{Influence}

Notwithstanding concerns about effectiveness, the findings of our study suggest the senate is a forum for discussing matters and that most senate members characterise themselves as active participants in university governance who believe they are able to influence decisions. Generally, the study shows that senate members feel they have the information necessary to fulfill their responsibilities and that they have the capacity to make difficult decisions associated with institutional governance in this complex environment, even if they express reservations about whether this is actually occurring. 
Discussions of institutional autonomy in the Canadian context are framed in terms of universities' relationship to government. Canadian higher education has been characterised by high levels of university autonomy for most of this century. Historically, there have been no direct attempts by government to interfere with, or curtail, institutional autonomy through changes in institutional governance arrangements but subtle changes over time are having a major impact. There is increasing evidence of indirect intervention by both provincial and federal levels of government through attempts to steer, from a distance, institutional activities through funding mechanisms. The new trends evidence a more subtle kind of change in university decision-making. Both the mechanisms and the broader higher education policy encourage university partnerships with industry which introduces an added agent to the autonomy discussion in Canada. While university-industry partnerships are not a new phenomenon, what is new is the nature and degree of university-industry collaboration today in Canadian higher education. Some scholars (i.e. Currie and Newson 1998) argue that these partnerships are presenting new and particularly difficult challenges to institutional autonomy because the new arrangements are cloaked in funding mechanisms which the universities are willingly embracing. They argue universities are selling their prestige, knowledge creation, human resources and other intellectual activities for very little monetary return. One of the most serious consequences of this trend is the influence on the academic balance and focus of the university.

Autonomy issues are also raised by the fact that new policy initiatives may be reshaping the nature of universities and academic enterprise with little or no public debate or participation from the senate. The senate's role in deciding the direction of the university in the current environment is constrained. This trend is notable because the governance reforms of the late 60 s and early 70 s were designed to strengthen university selfgovernment dividing the authority between the corporate board and the academic senate. The governance arrangements became more participatory, decentralised and complex and the powers and autonomy of the university president decreased (Cameron 1992). Our study reveals that power may be shifting in favour of the corporate board and senior administration and suggests the university senate may be declining in authority as an institutional decision-making body.

At the same time authority is also moving to locations outside the university. Current higher education policy favours partnerships with industry, collaborative networks and multi-institutional centres and projects. This has created decision-making bodies external to the univer- 
sity (although with university representation) taking decision making out of the university. However, it is not clear that faculty participation in decision-making will necessarily decline. The academic capitalism thesis speculates that globalisation will lead to certain units being favoured over others based on revenue generating activities at the department level. If this occurs then there is likely to be an impact on the faculty role in decision-making at the institutional level in forums such as the senate.

The findings of this study raise important questions concerning the role of 'traditional' academic decision-making structures in an environment of new policy pressures that have dramatic implications for universities. Our findings suggest there is a significant difference between the role that senators feel they should play in academic decision-making and the role these bodies actually play in university governance. Recognising important variations by institutions, our overall sense is that the Canadian senate is not involved in important university discussions about research and budgets in a way that one might expect. Given that the bicameral decisionmaking structure in Canadian universities emerged, in part, as a response to government interference in the university's academic decision-making it is interesting to note that the senate's lack of involvement in these current issues comes at a time when government and industry interest in universities is increasing.

\section{ACKNOWLEDGEMENT}

The authors are grateful for the financial support provided by the Social Sciences and Humanities Research Council of Canada.

\section{NOTES}

1. For the purpose of this paper we use the word 'senate' as a generic term referring to the senior, central academic decision-making body of a university. For institutions with a bicameral governance structure, the term is used to refer to the senior academic body that operates in parallel with the governing board. For institutions with a unicameral governance structure, the term is used to refer to a senior decision-making body that has been assigned some degree of responsibility over academic matters by the central governing body.

2. It is important to note that the University of New Brunswick has two senates: one for the Fredericton campus and one for the St. John campus. We treat these senates as two distinct bodies.

3. Overall gross expenditures on research and development increased - although the share of the higher education sector in the national research effort declined (AUCC 1999b). 
4. It is important to note that private investment in university research and development in Canada lags behind many OECD countries and although overall business investment in university-based research has increased dramatically in the last decade it still remains approximately half the OECD average (AUCC 2000).

\section{REFERENCES}

Alexander, W.J. (ed.) (1906). The University and its Colleges - The University of Toronto, 1827-1906. Toronto: The Librarian (University of Toronto).

AUCC (1999a). Trends: The Canadian University in Profile. Ottawa: Association of Universities and Colleges of Canada.

AUCC (1999b). Brief. Research and Education: The underpinning of innovation. Canada as a knowledge-based and innovative society. Ottawa: AUCC.

Axelrod, P. (1982). Scholars and Dollars: Politics, Economics, and the Universities of Ontario, 1945-1980. Toronto: University of Toronto Press.

Buchbinder, H. \& Rajagopal, P. (1993). Canadian Universities and the Politics of Funding. In P. Altbach \& D.B. Johnstone (eds) The Funding of Higher Education: International Perspectives. New York: Garland.

Cameron, D. (1992). Institutional Management: How Should the Governance and Management of Universities in Canada Accommodate Changing Circumstances? In J. Cutt \& R. Dobell (eds) Public Purse, Public Purpose: Autonomy and Accountability in the Groves of Academe. Halifax: Institute for Research on Public Policy, 167-192.

Cameron, D.M. (1991). More than an Academic Question: Universities, Government and Public Policy in Canada. Halifax: Institute for research on Public Policy.

Canada Foundation for Innovation (2000). http://www.innovation.ca

Corry, J.A. (1970). Farewell the Ivory Tower: Universities in Transition. Montreal: McGillQueen's University Press.

Council on Ontario Universities (2000). Ontario Universities - 1999. Resource Document. Toronto: COU.

Currie, J. \& Newson, J. (1998). Universities and Globalization: Critical Perspectives. Thousand Oakes: Sage.

Cutt, J. (1990). Universities and Government: A Framework for Accountability. Halifax: Institute for Research on Public Policy.

Duff, J. \& Berdahl, R.O. (1966). University Government in Canada. Toronto: University of Toronto Press.

Government of Canada (2000). Canadian Institutes of Health Research (CIHR). http://www.cihr.org

Hardy, C. (1996). The Politics of Collegiality. McGill: Queen's University Press.

Jones, G.A. (1996). Governments, Governance and Canadian Universities. In J.C. Smart (ed.) Higher Education: Handbook of Theory and Research (Vol. XI) New York: Agathon Press, 337-371.

Jones, G. (2000). The Canada Research Chairs Program. International Higher Education 21, 22-23.

Jones, G., Shanahan, T. \& Goyan, P. (1999). Canadian University Senates: A Preliminary Analysis of Composition, Structures, and Role. Paper presented at the Annual Meeting of the Canadian Society for the Study of Higher Education. Sherbrooke, Quebec, June.

Jones, G., Shanahan, T. \& Goyan, P. (2000). Academic Decision-Making in Canadian University Senates: An Analysis of Member's Views. Paper presented at the Annual 
Meeting of the Canadian Society for the Study of Higher Education. University of Alberta, Alberta, May.

Jones, G., Shanahan, T. \& Goyan, P. (2001). University Governance in Canadian Higher Education. Tertiary Education and Management 7, 135-148.

Jones, G.A. \& Skolnik, M.L. (1997). Governing Boards in Canadian Universities. Review of Higher Education 20(3), 277-295.

Macdonald, H.I. (1976). Universities, Government, and the Public. Canadian Journal of Higher Education 6(1), 51-58.

Newson, J. (1992). The Decline of Faculty Influence: Confronting the Effects of the Corporate Agenda. In W. Carroll, L.C. Ruffman, R. Currie \& D. Harrison (eds) Fragile Truths: Twenty-Five Years of Sociology and Anthropology in Canada. Ottawa: Carleton University Press, 227-246.

Newson, J. \& Buchbinder, H. (1990). Corporate-University Linkages in Canada: Transforming a Public Institution. Higher Education 20, 355-379.

Paquet, G. (1988). Post-Secondary Education - an Enterprise Less than Optimally Managed? In G. Paquet \& M. von Zur-Muelen (eds) Education Canada? Higher Education on the Brink, 2nd edn. Toronto: Canadian Higher Education Research Network, $1-10$.

Rhoades, G. (1998). Managed Professionals: Unionized Faculty and Restructuring Academic Labor. New York: State of New York Press.

Slaughter, S. \& Leslie, L. (1997). Academic Capitalism: Politics, Policies and the Entrepreneurial University. Baltimore: John Hopkins.

Higher Education Group

Department of Theory and Policy Studies in Education

Ontario Institute for Studies in Education

University of Toronto

252 Bloor Street West

Toronto, ON M5S 1 V6

Canada

E-mail: gjones@oise.utoronto.ca 